\section{Typhus Fever in the United States}

In a recent communication to the permanent committce of the International Office of Public Health (Bull. Off. internat. d'hyg. publ., 30, 1780; 1938), Surgeon-General H. S. Cumming stated that endemic typhus transmitted by fleas, as distinct from classical typhus transmitted by lice, of which no case had occurred in the United States recently, was on the increase in the United States, where three thousand cases had been reported in 1937. In addition to an increase in the number of cases, there had been an extension of the disease into the interior of the country from its original foci on the Atlantic coast and Gulf of Mexico. Typhus was now being notified in the north of Alabama and Georgia and in Tennessee. In recent years, endemic typhus had shown a tendency to spread from the towns to the rural areas, especially those in which pea-nuts were grown on a large scale, which suggested that the grey rat, a well-known reservoir of the disease, was being attracted into the rural districts by this kind of food. Another reservoir of the disease was a native rodent known as the Oldfield mouse, and about a dozen other native rodents which had been found to be susceptible to infection by typhus were potential reservoirs of the disease. The case mortality of endemic typhus is below 5 per cent, most of the deaths occurring in patients more than fifty years of age.

\section{The National Research Council of Japan}

THE report of the National Research Council of Japan, volume 2, No. 7, covering the period April 1937-March 1938, lists the serial publications issued during this period and includes notes on the general meoting of the Council and on divisional and com. mittee meetings as well as on the international scientific meetings at which the Council was repre. sented. Discussions at meetings of the Committee on Pacific Investigation have dealt with fishes of the Pelew Islands, the fluctuation of water temperature in the north-eastern sea region adjacent to Japan of the North Pacific Ocean, the rertical distribution of plankton in relation to submarine illumination and temperature, the propagative protection of the fow seal in the North Pacific. Discussions at meetings of the Committee on Engineering Research have covered television, the technical development of the broadcasting service and the research problems of electric arc welding. A full list of officers and members of the divisions and committees is included with a list of serial publications received from abroad and a table of serial publications already issued by the Council.

\section{Contraceptive Advice by Local Authorities}

Tue Family Planning Association directs attention to the fact that the Ministry of Health has during the last nine years issued four memoranda to local authorities in England and Wales on the provision of contraceptive advice for married women, but states that of 409 authorities so notified less than half hare taken any effective action. The Committee on Abortion in its report (see Nature, June. 1, p. 19) stated that the available facilities for contraceptive advice are inadequate and should be extended. The Family Planning Association, which incorporates soveral bodies that formerly dealt with questions of birth control, now has sixty-six voluntary elinics where advice on birth control and sterility is given to married women. Information on the subject may be obtained from the Secretary of the Association, 69 Eccleston Square, London, S.IV.1, and financial support would be welcomed.

\section{International Geological Congress}

The Second Circular for the eighteenth session of the International Geological Congress, London, 1940, has now been issued. The sessional meetings will be held during July 31-August 8, 1940, and the following ten subjects havo been listed for discussion: (1) metasomatic processes in metamorphism ; (2) rhythm in sedimentation; (3) the geology of iron-ore deposits ; (4) the geology of petroleum ; (5) the geology of sea and ocean floors; (6) the pliocene-pleistocene boundary; (7) faunal and floral facies and zonal correlation; (8) earth movements and organic evolution; (9) the geological results of applied geophysics; (10) the geology and paragenesis of the ores of lead and zinc. One of these, the geology and paragenesis of the ores of lead and zinc, will form the subject of a symposium to which recognized authorities have been asked to contribute. It is intended to issue these accounts before the Congress and to promote discussion on them at the sectional meetings.

Tre Circular contains details of a series of geological excursions covering most of the British Isles, together with a route-map indicating tho principal localities to be visited. In all, fourteen pre-Congress and ten post-Congress excursions are offered and a series of guide-books to be presented to the members is in courso of preparation. The arrangements for the Congress are now well in hand and upwards of 1,200 geologists from home and abroad have already signified their intention of being present. Sir Thomas Holland has been elected president of the General Organizing Committee and president-designate of the Congress. All communications should bo addressed to the General Secretaries, Eighteenth Session International Geological Congress, Geological Survey and Museum, Exhibition Road, London, S.W.7.

\section{Speleologists in South Wales}

THE fourth annual conference of the British Speleological Association will be hold at Swansea on August 5-9. In the preliminary programme it is announced that the meetings and administrative organization will bo housed in the buildings of the University College of Swansea, while the students' hostel has been placed at the disposal of visitors. The Conference will meet under the presidency of Dr. R. R. Marett, rector of Exeter College, Oxford, whose work in the exploration of the Mousterian cave of St. Brelade, Jersoy, is familiar to all students of palæolithic man. August 6 will be devoted to cave exploration, when the members of the Association 
will be divided into two bodies, one, the archæological section, visiting such famous archæological sites as Bacon's Hole, Paviland Cave, in which was found the well-known Paviland skeleton, and many years ago the late Prof. Sollas claimed to have discovered palæolithic painting, the Long Hole and others. Visits to the museum of the Royal Institution of South Wales and the Caermarthen Museum have also been arranged. The second section on this and succeeding days will engage in pot-holing, visiting Dan-yrOgof, Craig-yr-Nos, Penwyll, Porth-yr-Ogof, Wills caves, and others, all of noted difficulty of access. In addition to Dr. Marett's presidential address, a lecture will be given by Prof. T. Neville George, professor of geology in University College, Swansea, and a number of papers on speleological subjects have been arranged. The conference will be preceded by a camp at Lamb's Leer in the Mendips, where a camp held at Easter last discovered a new rift chasm, descending to a depth of $260 \mathrm{ft}$. below ground. This and other discoveries here of the south regional members of the Association will be reported at the Conference.

\section{Announcements}

Prof. WV. L. Bragg, Cavendish professor of experimental physics in the University of Cambridge, has been elected correspondant of the Section of Mineralogy of the Paris Academy of Sciences.

THE Royal African Society has awarded silver medals to the late C. F. Massy Swynnerton, formerly director of tsetse research in Tanganyika Territory. Dr. Edwin W. Smith, editorial superintendent of the British and Foreign Bible Society and editor of the Journal of the Royal African Society, and Miss Margery Perham, research lecturer in colonial administration in the University of Oxford.

Mr. Frederick P. Mills hrs been appointed honorary secretary of the North of England Institute of Mining and Mechanical Engineers, Neville Hall, Newcastle-upon-Tyne, 1.

The first award from the Anna Fuller Fund of New Haven, Connecticut, has been made to Prof. Ernest Kennaway, Prof. J. W. Cook, Dr. C. L. Hewett, Dr. I. Hieger and Dr. William Mayneord, who are all workers in the research department of the Royal Cancer Hospital (Free), London. The prize, which is worth about $£ 1,500$, is awarded for a "real and outstanding contribution to knowledge on the subject of the cause, care, prevention or cure of cancer".

THe Thirteenth International Congress of Zoology, which should have been held this year at Rio de Janeiro, will take place in July or August of next year. Further information can be obtained from the Secretary-General, 55 rue de Buffon, Paris, 5.

As international course of malariology will be held at the Institute of Malariology, Rome, on July 25-
September 20. The fee is 400 lire. Further information can be obtained from the Istituto di Malariologia, Policlinico Umberto 1, Rome.

A FREE courso on instruction in the history of medicine will be held at the Institute for the History of Medicine, Berlin, by Profs. Diepgen and Zeiss and Drs. Artelt and Heischkel on July 25-27. Further information can be obtained from the Institute, Universitätsstrasse $3 \mathrm{~b}$, Berlin, N.TV.7.

Av International Air Congress will be held at Stratford-on-Avon during July 8-13, 1910, organized by the Royal Aeronautical Society, at which there will be papers and discussions on the technical aspects of aviation. Further information can be obtained from the Organizing Secretary, International Air Congress 1940, 4 Hamilton Place, London, W.1.

Tre eleventh Congress of the International Union against Tuberculosis will be held in Berlin during August 11-September 20 under the presidency of Dr. Otto Walter. The discussion will be confined to three principal subjects: (1) the problem of the virulence of the tubercle bacillus, (2) the interest of tuberculosis in subjects more than fifteen years of age, (3) the re-adaptation of tuberculous patients for work. Further information may be obtained from the Union internationale contre la tuberculose, 66 Boulevard Saint-Germain, Paris $6^{\mathrm{e}}$.

A photographic competition for pictures of wild flowers and plants has been organized by the Green Cross Society, 47 Victoria Street, London, S.IV.1. The general object of the competition is to counteract the temptation to pick wild flowers or to uproot the plants. At the same time it is hoped to stimulate interest in and knowledge of this miniature and delightful form of wild Nature-including grasses, sedges, ferns and even fungi. Further informa. tion can be obtained from the Secretary of the Society.

Accordisa to international statistics, the population of the globe at the end of 1937 was $2,134,000,000$. Half this number belonged to Asia. Europe had $297,000,000$ inhabitants; the most thickly populated countries were Germany, England and France.

A New international "Address Book of Plant Taxonomists, Geographers, and Ecologists" is being prepared by the editors of Chronica Botanica and will be issued in the near future in the new series of "Plant Science Books". The Address Book will not only give the names and addresses of men of science included, but also their scientific interests, together with a conspectus of current and planned research. As it is no longer practicable to compile an address book for the whole of plant science, it is hoped that similar address books will be prepared for the other branches of the plant sciences. Further information can be obtained from the Editor, Chronica Botanica, P.O. Box 8, Leiden, Holland. 